DOI https://doi.org/10.30525/978-9934-26-039-1-16

\title{
СПОНУКАЛЬНІСТЬ І БАЖАЛЬНІСТЬ: ПРОБЛЕМА РОЗРІЗНЕННЯ ВОЛІТИВНИХ ЗНАЧЕНЬ
}

\author{
Умрихіна Л. В. \\ кандидат філологічних наук, доцент, \\ доиент кафедри українознавства і лінгводидактики, \\ докторант кафедри украӥнської мови \\ Харківського національного педагогічного університету \\ імені Г. С. Сковороди \\ м. Харків, Україна
}

Спонукальність і бажальність репрезентують фрагменти загальної системи функціонально-семантичної категорії модальності, завдяки якій мовлення фіксує процеси та стани позамовного світу речей, відбиваючи різноманітні відношення до дійсності.

Відмінність у продукуванні бажального і спонукального значень зумовлює формування унікальної природи кожного, незважаючи на належність до однієї сфери виникнення - волітивної.

У зоні волевиявлення опиняються усі можливі прояви власної волі мовної особистості, об'єднуючи не тільки бажальність, спонукальність, а й необхідність, повинність та ін., що мають тенденцію до співіснування й взаємопроникнення. Відповідні модальні значення часто перетинаються й нашаровуються один на одний, впливаючи на функціонування й загальну семантику кожного, що проблематизує встановлення чітко окреслених меж між ними.

Уважають, що якщо мовець спонукає адресата здійснити дію, то він первинно має бажання до цього. Таке положення демонструють, зокрема, дефініції відповідних мовних явищ, наприклад: «імператив виражає волевиявлення мовця - наказ, вимогу, спонукання тощо виконати бажану для нього дію чи набути бажаного для нього процесу чи стану» [1, с. 387]. Проте в окремих ситуаціях спонукальність може не виявляти цього імпліцитного компонента, як-от у разі дозволу, коли реалізації певного факту бажає адресат, а не мовець. Також характерна елімінація бажального складника у спонукальних висловленнях, використаних у функції поради, оскільки мовцем може керувати не особисте бажання, а усвідомлення доцільної необхідності якогось факту ірреальної дійсності, здійснення якого слугувало би на користь адресата. 
Якщо за названих умов відсутність бажання відчутна цілком дистинктивно, то в ситуаціях інших різновидів функціонування спонукального значення наявність/відсутність названого семантичного компонента має хезитаційний характер. Не можна категорично стверджувати, що в основі формування будь-якого спонукального висловлення, лежить саме бажання мовця, а не інші мотиви його продукування. Філософи мови застерігають від абсолютного ототожнення понять воля, волевиявлення, бажання, для пошуку істини занурючись у підвалини екзестенційносихологічного розуміння(бачення людського бутя [3, с. $61 ; 5$, с. 173$]$.

Волевиявлення передбачає спрямовану мисленнєво-мовленнєву діяльність особистості, засновану на автомотивації, рівень якої зумовлений ступенем усвідомленості мети. Спонукальність відбиває вищий ступінь автомотивації особистості мовця, коли спрямованість на об'єкт задоволення поєднана з чітким уявленням про шляхи реалізації задуму. Бажальність же віднесена до початкового етапу формування вольового акту, коли спрямованість на об'єкт не підкріплена усвідомленням можливого способу досягнення мети, тому волевиявлення не виходить за межі особистісних мрій, має внутрішній характер вияву. Тож спонукальність можна вважати проявом вольової активності, а бажальність - вольової пасивності.

Спонукальність позначена більш раціональним характером, бажальність, натомість, відрізняє відносна емоційність. Недарма бажальне значення визнають як емоційно забарвлену абстраговану спрямованість до якоїсь дійсності й говорять про здебільшого афективність його продукування.

За спонукальності суб'єкт свідомо скеровує власну діяльність, вона, як правило, не має спонтанного характеру, на відміну від бажальності, для якої притаманна миттєвість виникнення мовленнєвої ситуації.

Волевиявлення, як обо'язковий семантичний компонент бажального та спонукального значень, фіксує неоднаковий вектор їх волітивного спрямування: якщо бажальність демонструє автоволітивність, то спонукальність завжди ототожнена 3 волітивними відношеннями між адресантом i адресатом, що, зокрема, відбивають чисельні дефініції відповідних лінгвістичних термінів, наприклад: [2, с. 24; 4, c. $207 ; 6$, с. 64].

Спонукальність, зумовлюючи ситуацію прямого спілкування, виявляє іманентну ознаку його семантики - апелятивність. А от бажальність виявляє тенденцію до автозвернення.

Апелятивність спонукального значення забезпечує реалізацію його специфічної семантичної ознаки - каузативності, яка засвідчує впливову 
силу мовленнєвого висловлення на шляху до перетворення дійсності. Бажальність у своїй основі заперечує наявність каузативності. Бажальні висловлення не претендують на таку результативність висловлювання, як у разі спонукальних, вони не мають проекції на очікувані термінові або не визначені в часі перетворення.

Забезпечуюючи виконання основної функції мови - комунікативної спонукальні і бажальні висловлення відрізняються тим, що перші проектовані на міжособистісну мовленнєву взаємодію, а останні такої взаємодії не потребують й більшою мірою тяжіють до реалізації експресивної функції мови.

Аналіз спонукальності і бажальності доволяє окреслити основні семантичні конституенти відповідних модальних значень: спільні та індивідуальні. Обидва є волітивними, ірреальними суб'єктивно-модальними значеннями. Основними конституентами спонукальної семантики $\epsilon$ потенційність, адресованість, апелятивність, каузативність, волюнтативний вплив, націленість на результат, регулятивний характер передаваної інформації.

Особливостями бажальної семантики $\epsilon$ когнітивний характер передаваної інформації, емоційність, автозверненість; припущення власне ірреальності, не лише потенційності; відсутність таких ознак, якот: адресованість, апелятивність, каузативність, вплив на слухача, націленість на результат.

\section{Література:}

1. Вихованець І. Р., Городенська К. Г., Загнітко А. П., Соколова О. С. Граматика сучасної української мови. Морфологія. К.: Видавничий дім Дмитра Бураго, 2017. 752 с.

2. Каранська М.У. Синтаксис сучасної української літературної мови: Навч. пос. К.: НМК ВО, 1992. 400 с.

3. Мэй Р. Экзистенциальные основы психотерапии // Экзистенциальная психология. Экзистенция. М.: Апрель Пресс, Изд-во ЭКСМО-Пресс, 2001. С. 59-67.

4. Мясоєдова С. В. Категорія спонукання і ії̈ вираження в непрямих висловленнях сучасної української мови: дис. ... канд. філол. наук: 10.02.01. Харків, 2001. 178 с.

5. Рубинштейн С. Л. Избранные философско-психологические труды. Основы онтологии, логики и психологии. М.: Наука, 1997. 463 с.

6. Харченко С. В. Семантико-синтаксична та комунікативна структура речень спонукальної модальності: дис. ... канд. філол. наук: 10.02.01. K., 2001. 207 c. 